\title{
Common Assessment in Multi-Deprived Schools: The Case of Flood-Prone Schools in Western Kenya
}

\author{
Dr Gloria Erima \\ Postdoctoral fellow \\ Department of Education and Curriculum Studies \\ University of Johannesburg, South Africa
}

\begin{abstract}
The paper draws from a larger doctoral study, conducted between 2013 and 2016 in five floodprone schools in western Kenya. The mixed methods research investigated: a) how these schools promote epistemological access (EA) and, b) the challenges they encounter towards a socially-just educational experience and comparable learning outcomes to learners. Findings suggested the importance of developing capabilities in a socially-just environment towards achieving (equitable) epistemological access (E)EA) in deprived school environments. There is no question that EA is about schools ensuring the development of capabilities among all learners. To that end, this paper explores the impact of assessment and learner outcomes as determining proxies to epistemological access (EA) and educational progression. It provides an understanding of how EA is measured and how we gauge the extent of learning in disadvantaged schools. In so doing, the paper seeks to provide a clearer conceptual understanding of how modes of assessment and learner outcomes influence (equitable) epistemological access and the educational progression of learners in different learning contexts. It also suggests a model which may be useful for developing policy around curriculum evaluation in multi-deprived settings. This consideration would contribute to the broad concern of social justice in education across all levels in education.
\end{abstract}

Keywords: assessment; learner outcomes; epistemological access; equity; social justice

\section{Introduction and background}

'Assessment' is an integral part of a course curriculum (Subheesh \& Sethy, 2020). It is an essential component of teaching-learning processes that influences both learners and teachers (Dziob et al., 2018). Broadly, assessment means measuring the achievement of learners (Sieborger \& Macintosh, 2002). The fact that assessment is and continues to be part of education is no longer a matter for debate. However, education assessment is littered with paradoxes, because of the broader context of its role in educational progression. However, I submit to the view that there may exist as many definitions and examples of education/learner outcomes as there are authors, depending on the education system and where it is implemented. Equally, many perceptions exist about assessment and how it is perceived to be promoting learning, within and outside of the education arena (Leyendecker et al., 2008). Seen in this way, the act of assessment itself is not as important as what comes before and after it (Sieborger \& Macintosh, 2002). That said, this discussion attempts to 
connect assessment and learner outcomes, the way they shape educational progression (EA) and, eventually, the development of individual capacities in disadvantaged schools.

This paper is structured in four main grounds: 1) objectives of the research, 2) the ideal dimensions and modes of assessment in relation to the Kenyan education system, 3) a literature review on learner outcomes and how these are measured within the Kenyan context, and 4) learner outcomes and their impact on educational progression on primary school pupils in deprived settings. The paper concludes with a model on how assessment and education progression in disadvantaged schools may be improved.

\section{Research purpose and statement of the problem}

The overall aim of the research study was to explore how equitable epistemological access (E)EA may be achieved in flood-prone primary schools in Western Kenya. The theoretical basis in this research lies in equitable educational attainment; the extent to which it fosters key capabilities in disadvantaged schools; and the social injustices arising from this relationship. I locate the paper within the discourse of capabilities and social justice, premised on 'Sen's capability approach' (Sen, 2017) and Nancy Fraser's social justice framework (Fraser, 1999) as the theoretical basis for my argument. This paper makes a deliberate attempt to expose the debate regarding the role of education in developing capabilities with reference to assessment in disadvantaged schools. My assumption is that assessment modes and practices influence learner outcomes in different learning contexts.

Educational outcomes in Kenya are measured through high-stakes exams at standard Eight (end of Primary) and Form Four (end of secondary school). These exams determine the chances for a student to proceed to the next level of education (Erima, 2017). Kenya subscribes to a common curriculum and examinations with the intention of levelling up the playing field for all pupils, regardless of their origin and background (Branyon, 2013). It is assumed that when pupils pursue a common curriculum, they attain equal education. However, the key questions this paper battles with are:

1) To what extent has the objective of equality of educational opportunity been achieved in some areas?

2) If a common curriculum and a national examination are used to gauge the extent of learning, are disadvantaged pupils deprived of education and its benefits from the onset?

\section{Review of Literature}

The main research objective was to investigate ways in which (E)EA in flood-prone schools can be achieved. This was guided by two research questions: a) how flood-prone schools promote physical and epistemological access for learners; and b) ways in which current strategies in schools are perceived to be effective in promoting both the physical and epistemological access.

It is a fact that physical access to schools is not as easy in flood-prone areas as it would be in secure areas of Kenya (Maina \& Maringe, 2020). The occurrence of floods has been accompanied by barriers to learning, which prevents pupils' optimal education in these areas. Many empirical studies, including that of Masese et al. (2012), Okuom et al. (2012), and Achoka and Maiyo (2008) have been undertaken on what support is/should be given to pupils in flood-prone areas to enrol in schools. Unfortunately, no research seems to look holistically at factors that contribute to EA. There is little information on the acquisition of learning skills (EA) by these pupils. Existing data is not provided in a coherent manner. The focus has been on segmented areas of learning aspects, e.g. time on task, resources, teacher availability and instruction, among others. My purpose is having a suggested model that incorporates a learning environment that is appropriate for providing the essential rationale for EA (Morrow, 2009), as far as assessment is concerned. 
Existing literature depicts EA as a fairly under-researched concept, that still lacks a precise definition (Du Plooy \& Zilindile, 2014). Muller (2012) defines epistemological access as the intent to move beyond the physical or formal access to meaningful access to education. Du Plooy and Zilindile (2014) conceptualise EA as providing educational access through quality education. For me, EA speaks to the access to quality knowledge and the need for learners to have comparable outcomes. This according (Erima, 2017), denotes

the access to knowledge, skills and attitudes that enable learners to be successful in national examinations and promote their progression to higher levels of learning and their persistence in any given cycle, without contributing to different forms of education wastage (p. 2).

In the literature the study examined, it emerged that EA may not be measured directly, but through indicators and proxies (Erima, 2017). Assessment and learner outcomes, therefore, became the best proxies of measurement in this study, to provide the most valid way of determining the extent of quality learning and instruction for any schooling period. The paper engages with the two proxies: assessment and learner outcomes, and the extent to which they determine EA and educational progression in disadvantaged schools. I evaluate the meaningfulness of the assessment practices in the Kenyan education context and strive to arrive at an understanding of how modes of assessment and learner outcomes would influence EA and the educational progression of an education system.

Many countries have made significant progress toward equitable educational opportunities for all. However, the chances for many students in disadvantaged schools to have an equal education remain separate and unequal, because of common assessment of learner outcomes (Clark et al., 2007). The paper introduces us to the complexity of the concept of assessment, highlighting its ideal dimensions and modes. It then delves into educational outcomes, regarding what they are, how they are measured and their impact on pupils' 'future progression' within the Kenyan context.

\section{Assessment}

In education, assessment is seen as the process or means of evaluating academic work, or 'gauging' the extent of learning (Joughin, 2010). It is no longer debatable that assessment plays a key role in the learning process. In order to monitor the learners' progress, various assessment methods are guided by two fundamental questions: 'To what extent have the knowledge and skills been acquired?' and 'What do learners still need to do to satisfactorily acquire the knowledge and skills?' (Lubisi, 1999).

The most important question behind any assessment framework, according to Lubisi (1999), is the 'why' and 'how' we assess. Our choice of modes (general nature, style and character) of assessment determines many aspects thereof (e.g. when the assessment should take place, who the assessor is, or who the main beneficiary should be). In short, the choice of mode will decide how we assess, what we assess and what we do with the assessments. To this end, there are issues that are still unclear about what the role of assessment is, especially in different learning contexts. It is important that any education system is clear about the mode of assessment that is employed, as well as its benefits.

\section{Choice of modes of assessment}

Depending on how and why assessment is done, the mode of assessment of an education system is based on one or more aspects below (Lubisi, 1999).

- Formal, where public examination takes place in deliberately contrived situations; or Informal assessments, that are day-to-day observations of students' behaviour and performance in class. 
- Final, where a final/terminal assessment occurs at the end of the year; or continuous assessment, that happens concurrently with the course.

- Formative assessment, that is usually informal and non-judgmental; or Summative, where assessment is mostly of a summative nature often used for grading, ranking and selection purposes.

- External, where public examinations are set and marked by external agents; or Internal, where assessment is moderated by the school.

- Process or Product-orientated assessment, where the end product reflects a smaller part of the process.

- Convergent assessment, that is usually characterised by only one correct answer; or Divergent answers, where there is no unique solution.

- Competitive assessment, where the outcome is largely based on competition, which is inherent in placing pupils/streaming.

\section{Learner Outcomes}

Education assessment yields feedback or results which we refer to as education/learner outcomes. Quite often, assessment is discussed alongside outcomes. How then does assessment link to learner outcomes? The study identified two common learner outcomes from literature: performance and progression (Spours et al., 2009).

Performance in education is the extent to which a student, teacher or institution has achieved intended educational goals. These are commonly counted in terms of examination results, primary completion rates, transfer rates and gross enrolment ratios (Leyendecker et al., 2008).

Progression in education is the movement between multiple developmental stages of education, grade levels and learner 'destinations' etc. This mostly follows the compulsory schooling age and education-to-employment transitions (Dickerson et al., 2020). The extent of progress can be measured through participation, attainment, learner retention and destinations (Spours et al., 2009). This paper focuses more on performance, specifically on examination results and primary completion rates (see Figure 1).

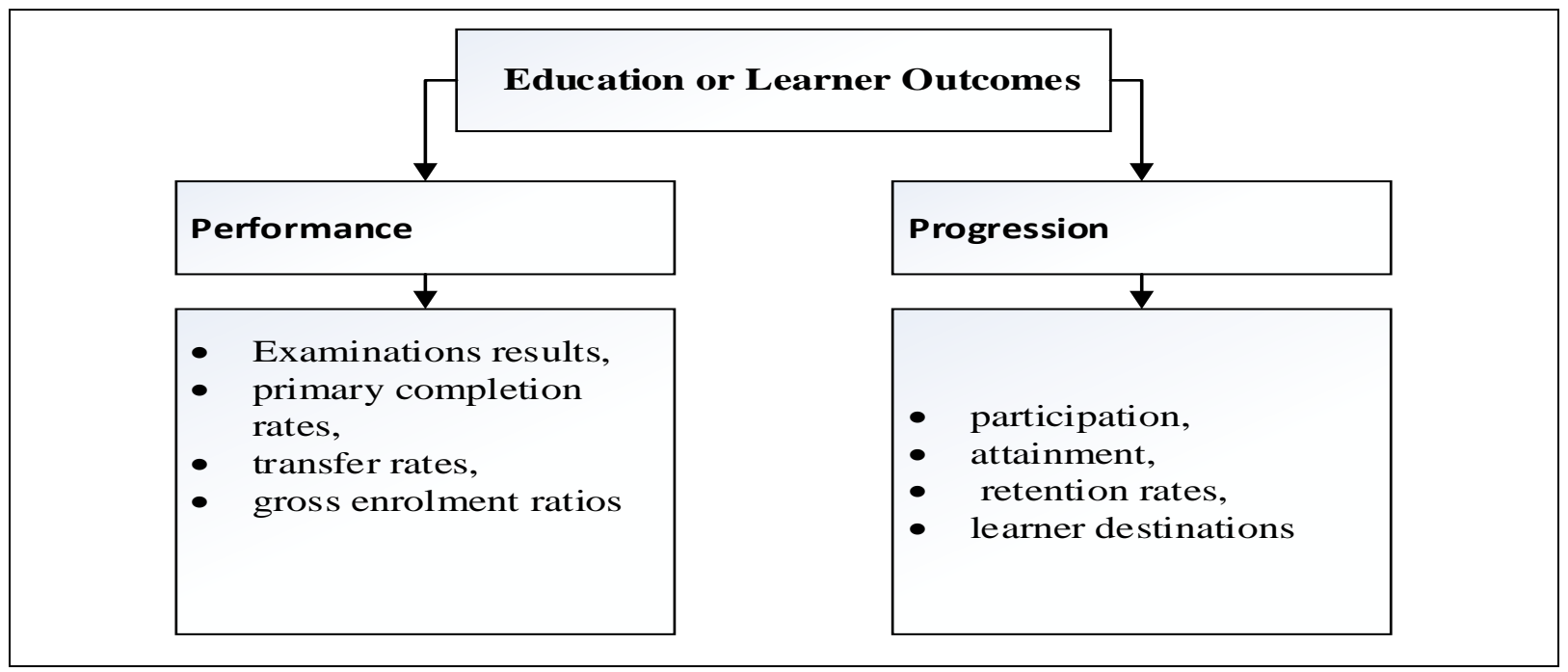

Figure 1. Education Outcomes and their measurement

Source: (Erima, 2017)

\section{Research Methods}

The larger doctoral study was concerned with answering the broad research question: How might equitable epistemological access (EEA) be achieved in flood-prone schools in Kenya. Based on the objective and research questions, the study aimed to investigate how schools endeavour to 
promote epistemological access. The study sample was limited to five flood-prone primary schools in Busia County, Bunyala Sub-county in Western Kenya. The schools were selected through a stratified random sampling strategy, based on performance and severity of floods. The research employed a convergent mixed methods approach, using interviews, a survey and focus group discussions (FGDs) to collect data (Erima, 2017). A convergent parallel design allows for the implementation of both the quantitative and qualitative data during the same phase of the research process (Creswell \& Clark, 2011). Interviews were conducted with parents and senior school managers (principals and senior teachers) in the selected schools. Additional interviews were conducted with representatives at the Sub-county education office, the local government and the disaster management departments. Respondents were selected through a purposive/purposeful sampling strategy. A questionnaire was completed by a total of 191 Standard 8 pupils from the five primary schools (Maina \& Maringe) (see appendix 1).

FGDs were conducted with 10 pupils, selected by class prefects from each of the five schools. The focus groups were used to encourage interaction amongst pupils about the concept of epistemological access (McMillan, 2012). The four ethical issues: informed consent, privacy/confidentiality, anonymity and the right to withdraw (Neuman, 2014) were observed during the study. No secondary data was used in this research. This being a mixed-methods study, the research aimed to achieve both validity and reliability (quantitative data) and trustworthiness (qualitative data) to strengthen findings (Cohen et al., 2011). Content validity was used to achieve soundness of quantitative data. With regard to reliability, the study employed SPSS to compute Chronbach's Alpha Reliability test to measure the consistency of the questionnaire. Qualitative data was analysed using ATLAS.ti. The study was approved by the Ethics Committee in Education of the Faculty of Humanities, University of the Witwatersrand, South Africa, Protocol Number: 2015ECE001D.

\section{Quantitative results Descriptive statistics}

Table 1 indicates that out of the 191 pupils in the five schools under study, 94 pupils were male while 97 were female.

Table 1. Gender: School cross tabulation

\begin{tabular}{|c|c|c|c|c|c|c|c|}
\hline \multirow[t]{2}{*}{ Gender } & & \multicolumn{5}{|c|}{ School } & \multirow[t]{2}{*}{ Total } \\
\hline & & A & B & $\mathrm{E}$ & C & D & \\
\hline \multirow{2}{*}{ Male } & f & 22 & 18 & 8 & 22 & 24 & 94 \\
\hline & $\%$ & $23.4 \%$ & $19.1 \%$ & $8.5 \%$ & $23.4 \%$ & $25.5 \%$ & $100.0 \%$ \\
\hline \multirow{2}{*}{ Female } & f & 26 & 19 & 7 & 25 & 20 & 97 \\
\hline & $\%$ & $26.8 \%$ & $19.6 \%$ & $7.2 \%$ & $25.8 \%$ & $20.6 \%$ & $100.0 \%$ \\
\hline
\end{tabular}

Source: (Erima, 2017)

The percentages are illustrated in Figure 2 below. 


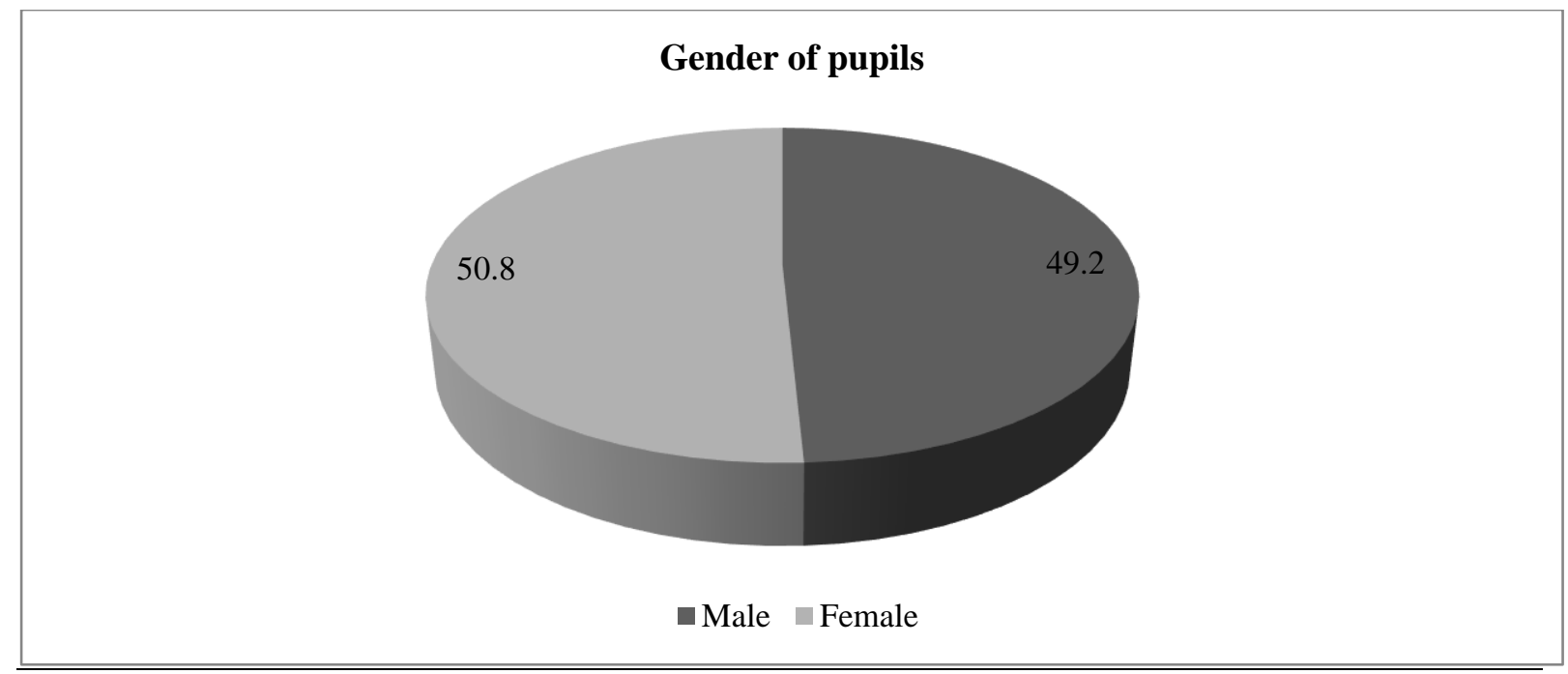

Figure 2. Gender of pupils

Source: (Erima, 2017)

Figure 3 below indicates that the 191 pupils in the five schools under study were within the age range of $13-19$ years.

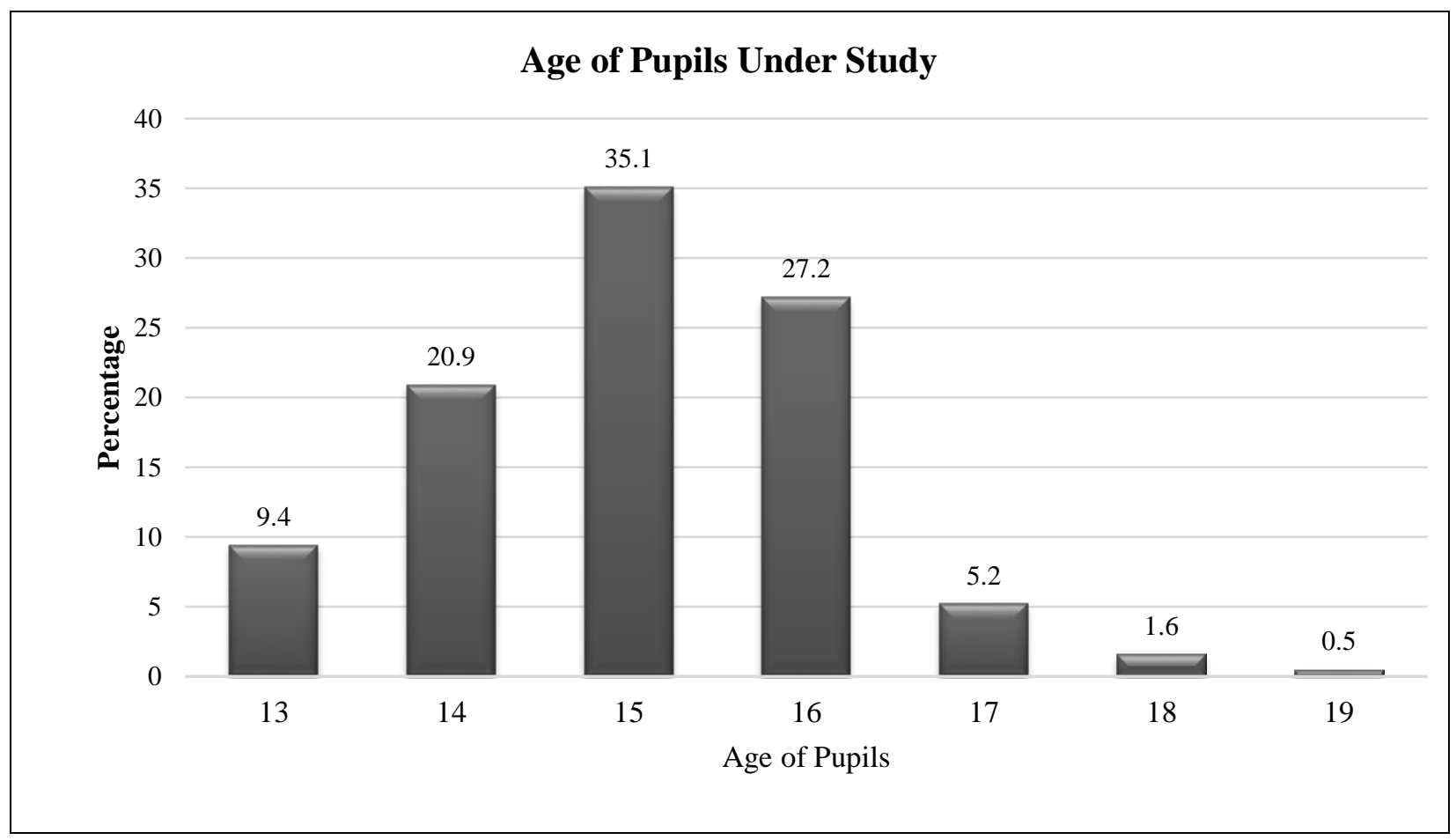

Figure 3. Age of Pupils

Source: (Erima, 2017)

In primary education in Kenya, pupils in Standard Eight should be fourteen years old on average. Table 2 indicates that $125(65.4 \%)$ out of the 191 pupils had repeated a class across the five schools. The pie chart in Figure 4 illustrates this data.

Table 2. Cases of repetition: School cross tabulation 


\begin{tabular}{|c|c|c|c|c|c|c|c|}
\hline \multirow[t]{2}{*}{ Repetition } & & \multicolumn{5}{|c|}{ School } & \multirow[t]{2}{*}{ Total } \\
\hline & & A & B & $\mathrm{E}$ & C & $\mathrm{D}$ & \\
\hline \multirow{2}{*}{ Yes } & $\mathrm{f}$ & 35 & 23 & 9 & 24 & 34 & 125 \\
\hline & $\%$ & $28.0 \%$ & $18.4 \%$ & $7.2 \%$ & $19.2 \%$ & $27.2 \%$ & $100.0 \%$ \\
\hline \multirow{2}{*}{ No } & $\mathrm{f}$ & 13 & 14 & 6 & 23 & 10 & 66 \\
\hline & $\%$ & $19.7 \%$ & $21.2 \%$ & $9.1 \%$ & $34.8 \%$ & $15.2 \%$ & $100.0 \%$ \\
\hline
\end{tabular}

Source: (Erima, 2017)

Figure 4. Cases of repetition

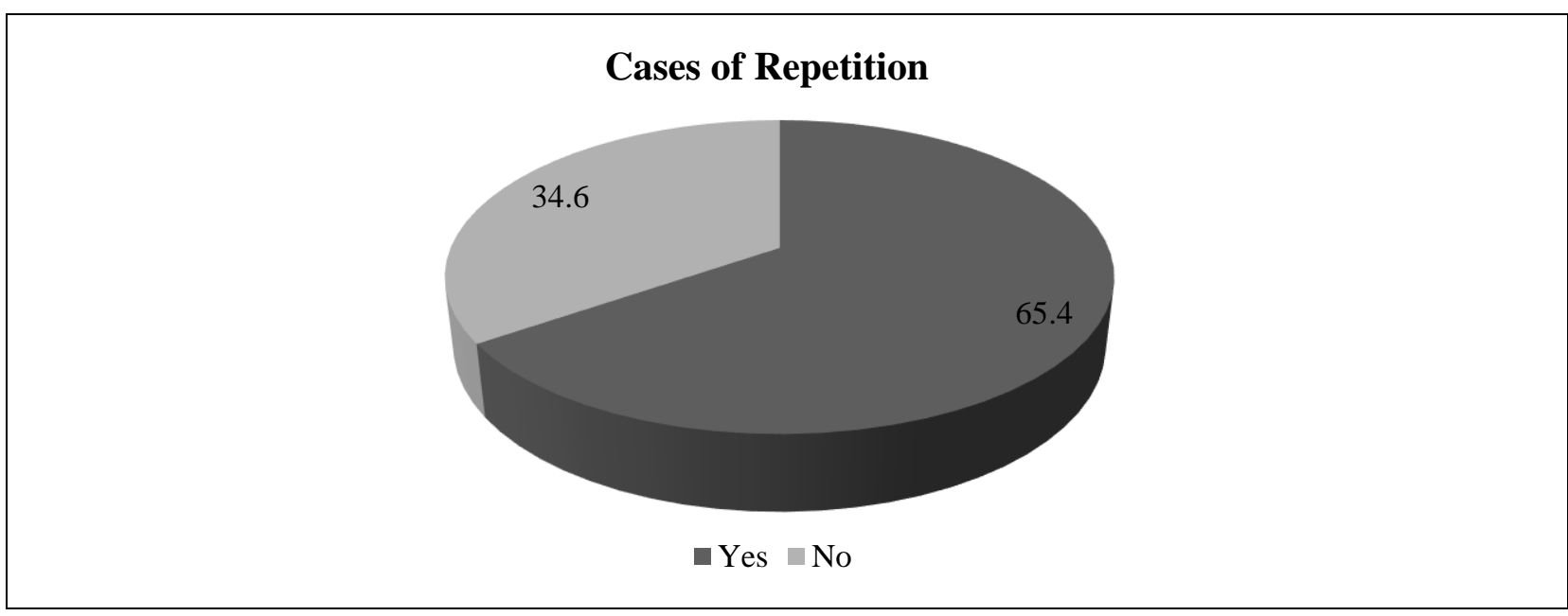

Source: (Erima, 2017)

Table 3 shows the reasons for repetition based on pupils' responses. The biggest cause of repetition, was 'poor performance at $46.3 \%$, followed by 'effects of floods' at $26 \%$.

Table 3. Reasons for repetition

\begin{tabular}{|l|c|c|}
\hline Reason & Frequency & Percent \\
\hline Because of fees & 22 & 17.9 \\
\hline Because of floods & 32 & 26.0 \\
\hline Because of poor performance & 57 & 46.3 \\
\hline Lack of a birth certificate & 2 & 1.6 \\
\hline Due to transfer & 8 & 5.7 \\
\hline Parents advice & 4 & 2.4 \\
\hline Total & $\mathbf{1 2 5}$ & $\mathbf{1 0 0 . 0}$ \\
\hline
\end{tabular}

Reasons for repetition Source: (Erima, 2017) 


\section{Findings}

This paper provides an understanding of how modes of assessment and learner outcomes influence (equitable) epistemological access (E)EA and the educational progression of learners in different learning contexts. Findings from the larger doctoral study revealed that: a) a common assessment does affect education progression in schools prone to floods in Western Kenya b) the mode and choice of assessment in Kenya affects the role of assignment and progression of learners in the schools under study c) education inputs and outputs in these schools affect learner outcomes.

\section{Common Assessment- Examinations}

The national curriculum is the basis for comprehensive national exams in Standard Eight (Grade 8 ) and Form Four (Grade 12), which are significant levels of progression in the education system (Stone, 2005). As the system is highly selective, advancement depends solely on students' performances in examinations, where only the strong achievers proceed to the next level of education. Therefore, a high pass rate in exams is key, for a student in Kenya to proceed to the next level. In flood-prone schools, there remains de-motivation for those who do not 'pass' national examinations as they are branded 'academically weak'. The result for these students is: dropouts, vocational training or non-lucrative courses, which deny pupils the rationality and freedom to choose and make a valuable life.

\section{Choice and modes of assessment}

Findings also revealed that the mode and choice of assessment, i.e. the why (purpose) and how (mode) we assess affect the role of assessment in disadvantaged contexts. That, the choice of mode decides how we assess, what we assess and what we do with the results. Findings showed that flood-prone schools undergo formal assessments only. This implies a national examination, based on a national curriculum, taking place in deliberately contrived situations (planned and controlled). Their evaluation is of a summative nature, often used for grading, ranking and selection purposes. The assessment practice in these schools is mostly external, with public examinations set and marked by external agents (examination boards). These are mainly intended for external users (i.e. school and university selectors) and, probably, the public. This means the system concentrates more on the product, usually an examination grade, which reflects a smaller part of the process. Since the product is key, assessment in these schools is still based on convergent assessment. National examinations at primary level are multiple-choice questions, based on convergent answers. They do not allow for any diversions (i.e. a pupil to supply new and relevant information), or a correct, but alternative, answer. This makes this assessment very competitive for grading and selection for further progression.

\section{Learner outcomes}

Findings revealed that learner outcomes in flood-prone schools are affected by inadequate input. A schooling environment is termed appropriate if it provides adequate level of inputs, such as personnel, adequate educational resources and facilities for the efficiency and effectiveness of the learning process. 'The greater the quality and quantity of inputs, the better the quality of output, which will satisfy the expectation of the society and the government' (Achoka \& Maiyo, 2008, p 157). In this case, inputs would include textbooks, teachers, pupils, sanitation facilities, funds and physical infrastructure (Maina \& Maringe). These undergo a process, during which they are planned, organised, implemented and controlled, towards meeting education goals (Munyi \& Orodho, 2015). 


\section{Discussion of Findings \\ Common Assessment}

Examination results in Africa are high stakes. They remain the dominant form of assessment for education and are a popular determinant for success and students' futures (Leyendecker et al., 2008). In this way, they hold great significance as a 'rite of passage', to education progression (Abagi \& Odipo, 1997). In Kenya, examinations encourage competition, which is viewed as a healthy way of determining the choice of schools and universities (Stone, 2005). It is believed that examinations hold great significance as a rite of passage, therefore pupils' futures depend significantly on their success. This has resulted in teachers teaching only towards examination success and mostly leaving out what will not be evaluated (Abagi \& Odipo, 1997).

In Kenya, progression in education is based on examination grades obtained, as evidenced by primary school leavers seeking admission to secondary schools. University places are offered to those with the highest aggregates (high achievers) based on subject grades (Stone, 2005). High achievers, it is assumed, have the motivation to think actively and deeply about social phenomena. Using examination grades as a measure, disadvantaged students do not only easily progress to higher levels, but also do not get absorbed into job markets. If examinations are, in themselves, affected by many other factors, what is the future progress of these pupils in societal engagement, if they are only measured by merit? Yes, examinations remain the best way to judge one's intellectual ability in Kenya, but only if other factors, both internal and external, are equal. The common curriculum and examinations have, therefore, largely failed to guarantee an equal education in flood-prone schools. In short, the playing field for pupils in these schools is not level.

\section{Choice of modes of assessment}

Based on the modes discussed, the assessment practice in Kenya can be contextualised as:

\section{Formal}

As indicated earlier, the most formal assessment in Kenya is a national examination based on a national curriculum for the purpose of uniformity. Although uniformity in assessment is fairly acceptable, it is most ideal only where we have equality of inputs, which result in equal outcomes and, therefore, equal opportunity. It is acceptable that differences in outcomes would arise from differences in efforts; and the resulting disparities would not be considered discriminatory or unfair (Adrogue, 2013). This paper addresses the fundamental questions on the objective of equality of educational opportunity vis-à-vis a common assessment method for pupils in disadvantaged schools.

\section{Final}

What exists in Kenya are termly and continuous assessment tests (CATs) that do not contribute towards the final examination grade. Continuous assessment is considered an expensive exercise to assess pupils, as it would usually need to take place at intervals (Abagi, 1999; see also Amutabi 2003). It would also be a good way to add a layer of assessment, especially for deprived pupils. This would bring out a true reflection of their capabilities, given the disparity in the quality of education due to floods. The new 8-4-4 curriculum intended to focus on continuous assessment and vocational training, to put an end to the examination-driven learning (Zuze, 2008) in Kenya. 'However, over the years, the 8-4-4 curriculum has been widely criticised for a myriad of reasons. The criticisms against this curriculum are that it is too heavily loaded with content, purely examinations-oriented, and generally violating the Rights of the Child by placing undue physical and psychological pressure on learners' (Kaviti, 2018, p. 84). Besides, the vast curriculum is said to have largely encouraged rote learning, forcing staff to teach exclusively for examination purposes. 


\section{Summative}

The Kenyan education system is mostly of a summative nature. Competitive purely examinationsoriented curriculum continues to dominate the education landscape, at both primary and secondary school levels (Erima, 2017; see also Zuze, 2008). Assessment in Kenya is hardly designed to help pupils to learn and progress, nor does it concentrate on positive encouragement and constructive criticism. Learning is a process that may vary, depending on the location where it is taking place. This needs to be accommodated and acknowledged in light of assessments, cultures and environments in schools. From data gathered, it is evident that there is an effort for school heads to provide continuous assessment to pupils in flood-prone schools - which is acknowledged. However, Kenya's education system provides little support and only acknowledges the final grade in the national examinations, despite the imbalance in learning inputs. It is evident that, when assessment is used for formative purposes, it is likely to show an uneven pattern of achievement designed for progress. It means that, when a number of assessments are used in a formative way, there has to be a valid means of putting together their results for summative purposes (Sieborger \& Macintosh, 2002).

\section{External assessment}

External assessment involves public examinations, set and marked by external agents (examination boards). This is mainly intended for external users such as schools, universities, employers and the public. Most teachers do not have much choice in this regard. To some extent, teachers are used as assessors in public examinations, as paid employees of the examination boards in setting and marking examinations papers. However, internal assessment does not necessarily mean an internal syllabus. One may very well assess an external syllabus through internal means (Lubisi, 1999). Alternatively, an internal syllabus may be assessed by a local consortium (a collaborating group) of teachers working on an agreed marking scheme, which is a form of external assessment. An internal form of assessment brings freedom of choice, as well as opportunities for field work and projects in more practical contexts. It also allows teachers to use their own detailed knowledge about the work and capability of individual pupils, whom they have known over a longer period of time. Though teachers' judgments may be biased or lack standardisation, internal assessment can well be applied in marginalised areas to allow for fairness in progression.

\section{Product-orientated assessment}

Looking at a pupil's final grade may possibly not allow one to assess to what extent the pupil has acquired the ability to use non-examinable skills. Furthermore, good grades favour the intelligent students while the less intelligent and the deprived only get de-motivated and progress less. Assessment tasks need to be accompanied by active engagement in learning, in order to demonstrate that learning has occurred (Joughin, 2010). In flood-prone schools, about three months of learning time is lost in one academic year, when flooding seriously occurs. There is usually little or no active engagement in learning, because these children, parents and teachers prioritise the impact of flooding. They prepare to sit the same national examination as their counterparts in secure schools and the chances are that the product (examination grade) will be average. If the grade happens to be reasonably good for progression, learning may still not have taken place, compromising their capability development.

\section{Convergent assessment}

In Kenyan primary schools, the national examination is still largely multiple-choice questions based on convergent answers. They do not allow for any deviations (i.e. a pupil supplying new and relevant information, or a correct, but alternative, answer). We know that the control of assessment should lie beyond the course into the world of practice (Joughin, 2010). Therefore, the use of holistic approaches to assessment needs to be reconsidered. Assessing creativity, imagination or problem formulation and solving situations is difficult with convergent answers. Similarly, 
assessment and evaluations that only test for methodological and social competencies will always encourage rote learning and memorising of facts, whatever the curriculum wishes to aim for' (Leyendecker et al., 2008). Accordingly, assessment procedures based solely on convergence, usually have profound effects on the curriculum, but they are not always beneficial for all learners, despite the learning context. This raises concerns for policymakers about how assessment can be improved to benefit pupils and the curriculum.

\section{Competitive}

From its historical roots, most assessment in schools has been competitive (Amutabi, 2003). It is argued that competition is a fact of life and the best possible way to gauge the extent of learning and that grading is necessary, as it enables selection for further education and the job markets. Furthermore, success or failure in competitive examinations provides appropriate feedback for parents and pupils, so that curricular and career choices can be made. The reality is that pupils, parents and employers expect competitive examinations, because they see competition as a motivator (Lubisi, 1999; Leyendecker et al., 2008). As a result, the school system is largely based on competition, which is inherent in placing pupils (streaming). From primary school, pupils are aware that those who read best are placed in one category, be it according to a stream, or seating arrangements. Those who fail examinations in secondary schools are reminded that they are not intelligent. The beneficiaries of this system are universities and employers, who are able to cream off the most successful pupils (Stone, 2005). Inasmuch as competition motivates many successful children, it only de-motivates the less able. There are non-competitive forms of assessment that measure pupil achievement against course objectives (criteria) with an aim to achieving learning objectives (mastery of learning) (Leyendecker et al., 2008).

From the colonial era to date, assessment in Kenyan schools has largely been competitive, where very few pupils value learning for its own sake. The majority of pupils' lives are characterised by competitive exam-based assessments to which 'examinations grades have been institutionalised as valuable learning' (Joughin, 2010). This has become the focus of attention for almost all pupils, teachers and parents in Kenya. Grading enables selection for further education and the job markets. It is therefore seen as necessary in Kenya. All stakeholders in the society judge educational success in terms of results (Leyendecker et al., 2008). Teachers and schools are often measured through ranking of national examination results of their students/pupils. Pre-school selection has been reported to influence parents to have their children attend the best primary and secondary schools (Zuze, 2008).

A competitive, purely examinations-oriented education system that is heavily loaded with content can certainly produce pockets of excellence (Zuze, 2008), but may do so by exerting huge pressure on educational materials. Perhaps, this should be an enduring lesson from Kenya's educational history. Such pressure is evident in widespread repetitive practices, high staff turnover and overcrowded classrooms in the Kenyan schools (Alubisia 2005). The effect increases twofold, when the education system is implemented in marginalised and underperforming areas. Schools in these areas endure learning, where quality, equity and efficiency are highly compromised, due to competition. As schools, universities and employers become major beneficiaries of this kind of system, vulnerable pupils are subjected to failure and wastage, due to competition, (Lubisi, 1999). I reiterate that there are non-competitive forms of assessment in Kenya that can measure pupil achievement, or mastery of content. It appears that teachers are not aware of the range of assessment possibilities in the five schools under study. They are also unaware that not all their pupils are best served by the existing assessment procedures and that some objectives may not be assessed adequately using traditional methods. What is key is that assessments tend to define the actual curriculum-and may cripple or steer it (Ramsden, 2003). 


\section{Learner Outcomes}

To reflect on EA in flood-prone schools, under the umbrella of assessment and learner outcomes, we mainly focus on performance and progression. Firstly, learner outcomes in Kenya are predominantly measured in terms of performance and progression, through examinations and further education, respectively. So intertwined are these two concepts, that for one to progress (progression) to the next level of education, one needs to have passed the examinations (measure of good performance) (Erima,2017). Secondly, performance and progression are more relevant outcomes at primary school level to advance our argument on EA in flood-prone schools. The outcomes are linked to educational inputs and outputs.

\section{Education Inputs, Outputs and Outcomes}

As mentioned earlier, appropriate input and outputs must accompany the learning process for efficiency and effectiveness. That, a greater quality and quantity of inputs translate into better outputs and outcomes (Achoka \& Maiyo, 2008). However, because education involves a range of complex processes, it is not practical to expect a straight-forward one-to-one relationship between inputs and outputs (Erima, 2017; Wildeman, 2008).

Outputs vs. outcome: According to Munyi and Orodho (2015), outputs relate to "what we do and with whom," while outcomes refer to "what difference this makes". Outputs would then concern aspects like curriculum, assessment, services and the participants. What difference this makes is a question about outcomes. An educational system is said to be inefficient if there is a discrepancy between inputs, processes and outputs (Munyi \& Orodho, 2015). A school system can be looked at as having inputs, processes and outputs, which produce feedback in the long run. Inasmuch as schools may produce feedback based on inputs, processes, outputs and outcomes, they remain open systems that respond to external influences in their attempt to achieve objectives (Munyi \& Orodho, 2015).

\section{Limitations}

The findings discussed should be considered in light of the limitations of the study. The first limitation is that the study draws data from five flood-prone schools, which is a very small sample, compared to the population and may undermine the accuracy of findings. Secondly, the study did not focus on EA of children beyond primary school level. Pupil attitudes and parental involvement may change, as pupils' progress to higher levels of learning. Transition and educational progress of pupils may play out differently in secondary schools, which have more boarding facilities. A final limitation of this study may be the choice of EA indicators used. These were contextualised through pre-determined indicators from literature. The study did not look beyond for other factors affecting learning in these schools, but only the nine considered as those that provide the essential rationale for EA. As a consequence, findings can be generalised only to an extent based on a specific location and time period.

\section{Contribution}

The paper provides a central focus of learner outcomes in flood-prone schools. In Figure 5, I suggest a model and recommendations which may be useful when developing policy around curriculum evaluation and policy in multi-deprived settings. 


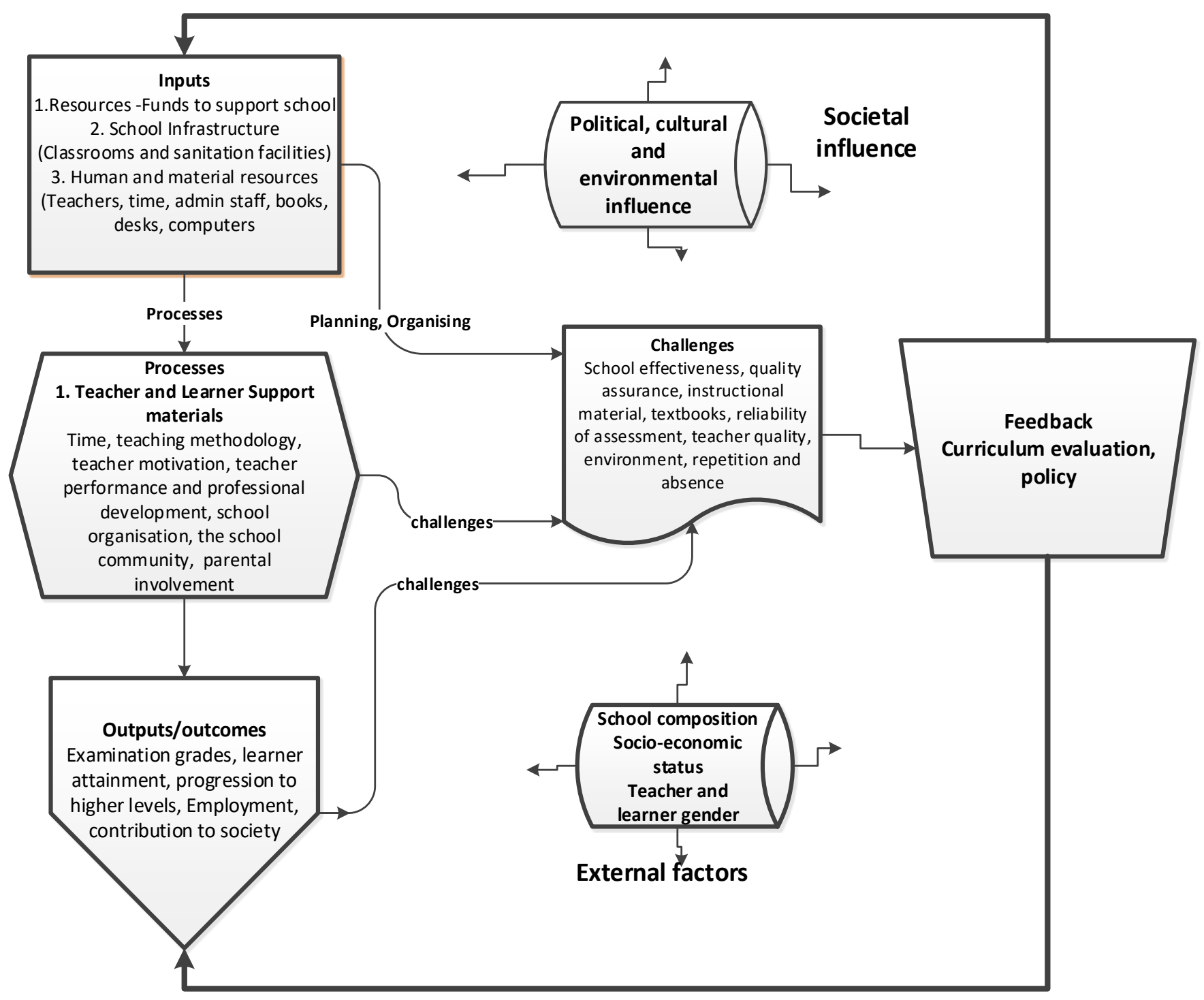

Figure 5. A school System: Inputs, Outputs and Outcomes

Source: (Erima, 2017)

Figure 5, above, provides a summary of what an appropriate school system would be like. There are three ways of looking at this:

- Scenario one means the inputs may be sufficient for the intended purpose, but the outcomes may be influenced by external factors.

- Scenario two, on the other hand, presents a school with insufficient inputs from the onset, which in turn yield insufficient outcomes.

- Scenario three demonstrates a combination of both scenarios one and two, where insufficient inputs yield insufficient outcomes, which are again affected by external factors. This is the case in flood-prone schools.

A system consisting of inputs, educational processes and outputs, as illustrated in Figure 5, denotes pupils' achievements-as one of the major indices reflecting the degree of efficiency of the primary education system (Munyi \& Orodho, 2015). Many research studies reveal that a number of factors, both internal and external, do influence pupils' achievements (Munyi and Orodho, 2015). In floodprone areas of western Kenya, there are hardly any facilities left in schools to promote school effectiveness, once flooding occurs (Achoka \& Maiyo, 2008). Due to a lack of learning facilities, 
pupils from these areas toil hard to compete on par with their counterparts from non-marginalised areas.

\section{Conclusion}

This paper has demonstrated the close link between assessment and learner outcomes and how they are used to gauge the extent of learning. I have discussed modes and the broad role of assessment in the Kenyan context. The paper has offered the challenge of examinations as a dominant assessment factor in Kenya and debated its impact on educational achievement for disadvantaged pupils. Since assessment is linked to learner outcomes, I have taken time to engage with two of the more common of these and their role in educational achievement and progression within multi-deprived settings. This paper suggests an input-output-outcome model that could serve as a tool for further research on EA in multi-deprived settings. More importantly, a comparative study on assessment factors for disadvantaged schools in different regions would be a good step to consider. To this end, the heart of achieving EA lies in the development of capabilities within a socially just environment. In conclusion, I assert that a common assessment affects learner outcomes, which in turn influence progression of learners within different social backgrounds in Kenya. At this point, a lot more remains to be done by all stakeholders to realise this goal.

\section{Notes}

The 2-6-3-3-3- system of education: Kenya has now rolled out a new education system to replace the 8-4-4 system. The preparations to roll out the 2-6-3-3-3- system (2 years of pre-primary, 6 years of primary, 3 years of junior and senior secondary each and 3 years of tertiary education) have been underway since 2017 . The entirely skills-based education system was piloted in April 2017 across 470 schools -10 in each county and was expected to replace the current 8-4-4 system in January 2018. The system will incorporate pupils' special needs and will enable learners to develop beyond academics, as well as focus on how pupils can use specific talent to improve life chances. In this system, pupils will be assessed through continuous assessment, not examinations.

Learners, Students and Pupils: The terms 'learners', 'students' and 'pupils' are used interchangeably by most people, depending on the country and the education system. In Kenya, the terms 'pupils' and 'students' are used in primary and secondary schools respectively. It should be noted that, at the time of writing this article, the term 'learners' is slowly gaining ground in Kenya, especially in the upcoming 2-6-3-3-3 curriculum that will replace the 8-4-4 system.

\section{References}

Abagi, O. (1999). Education for the Next Decade: A Demarcation of Imperatives. Kenya's Strategic Policies for the 21 st Century: Macroeconomic and Sectoral Choices. Nairobi: IPAR.

Abagi, O., \& Odipo, G. (1997). Efficiency of primary education in Kenya: Situational analysis and implications for educational reform (p. 33). Institute of Policy Analysis and Research.

Achoka, J.S.K., \& Maiyo J. (2008). Horrifying disasters in Western Kenya; Impact on education and national development. Education Research and Review, 3(3), 154-161.

Adrogue, C. (2013). Equality of educational opportunities at public primary schools in Argentina. education policy analysis archives, 21, 89.

African Network for the prevention and Protection against Child Abuse and Neglect (ANPPCAN). (2005). Review of the Status of Provision of Education to all Children in Kenya. Nairobi: Strategic Public Relations \& Research Ltd.

Alubisia, A. (2005). UPE myth or reality: A review of experiences, challenges and lessons from East Africa. OXFAM/ANCEFA, London. 
Amutabi, M. N. (2003). Political interference in the running of education in post-independence Kenya: A critical retrospection. International Journal of Educational Development, 23(2), 127 144.

Branyon, B. J. (2013). Enacting a Common Core Curriculum: The Kenya Study. The Delta Kappa Gamma Bulletin: Educational Research, 40-46.

Clark, R.W., Lappin, G., \& Jacobs, O.W. (2007) Equalizing Educational Opportunities for African American Students: The Evaluation and Evolution of Teacher Education, Peter Lang Publishing Inc.

Creswell, W. J., \& Plano Clark, V.L. (2011). Designing and Conducting Mixed-methods. (2 ${ }^{\text {nd }}$ Ed.). USA: SAGE publications Ltd.

Cohen, L., Manion, L., \& Morrison, K. (2011). Research methods in education. Routledge.

Dickerson, A., Morris, D., \& McDool, E. (2020). Post-compulsory education pathways and labour market outcomes (Vol. 26). Research Discussion Paper.

Du Plooy, L., \& Zilindile, M. (2014). Problematising the concept epistemological access with regard to foundation phase education towards quality schooling. South African Journal of Childhood Education, 4(1), 187-201.

Dziob, D., Kwiatkowski, L., \& Sokolowska, D. (2018). Class tournament as an assessment method in physics courses: A pilot study. Eurasia Joumal of Mathematics, Science and Technology Education, 14(4), 1111-1132.

Erima, G. (2017). Epistemological access in flood-prone primary schools of Western Kenya (Doctoral dissertation). University of the Witwatersrand, South Africa. https://wiredspace.wits.ac.za/

Fraser, N. (1999). Social justice in the age of identity politics: Redistribution, recognition, and participation. Culture and economy after the cultural turn, 25-52.

Joughin, G. (2010). Assessment, learning and judgement in higher education: A critical review. Assessment, learning and judgement in higher education, 1-15.

Kaviti, L. (2018). The New Curriculum of Education in Kenya: a Linguistic and Education Paradigm Shift. University of Nairobi.

Leyendecker, R., Ottevanger, W., \& van den Akker, J. J. H. (2008). Curricula, examinations, and assessment in secondary education in Sub-Saharan Africa. World Bank Publications.

Lubisi, C. (1999). Assessment in Education: Principles, practice and critique. University of Natal Press.

Maina, G. E., \& Maringe, F. (2020). Epistemological Access in Disadvantaged Schools: A Case Study of Flood-Prone Rural Schools in Western Kenya. In Inclusion as Social Justice (pp. 1435). Brill Sense.

Masese, A., Opiyo, R., Okayo, J., \& Ombui, N. M. (2012). Impact of floods on attainment of education for all (EFA) and vision 2030 in Nyando Basin. Kisumu County International Journal of Disaster Management and Risk Reduction, 4(2), 19-31.

McMillan, J. H. (2012). Educational research: Fundamentals for the consumer. HarperCollins College Publishers, 10 East 53rd Street, New York, NY 10022; World Wide Web: http://www. harpercollins. Com/college.

Morrow, W. E. (2009). Bounds of democracy: Epistemological access in higher education.

Muller, J. (2014). Every picture tells a story: Epistemological access and knowledge. Education as change, 18(2), 255-269.

Munyi, C. M., \& Orodho, J. A. (2015). Wastage in schools: What are the emerging internal efficiency concerns in public primary schools in Kyeni Division, Embu County, Kenya? Developing Country Studies, 5(6), 135-146.

Neuman, L. W. (2014). Social research methods: Qualitative and quantitative approaches. Allyn and Bacon.

Okuom, H. A., Simatwa, E. M., Olel, M. A., \& Wichenje, K. M. (2012). Assessment of factors that contribute to repetition and dropout of pupils in primary schools in flood prone areas of Nyando District, Kenya: An analytical study. Educational Research, 3(2), 190-201.

Ramsden, P. (2003). Learning to teach in higher education. Routledge. 
Sen, A. (2017). Collective choice and social welfare. Harvard University Press.

Stone, Marla. (2005). Kenyan Education Has Its own High Stakes Exams. The Texas Science Teacher, $7(1)$.

Siebörger, R., \& H, Macintosh. (2002). Transforming assessment. Juta and Company Ltd.

Spours, K., Hodgson, A., Brewer, J., \& Barker, P. (2009). Improving progression for younger learners in further education colleges in England. Journal of Vocational Education and Training, 61(4), 431-446.

Subheesh, N. P., \& Sethy, S. S. (2020). Learning through assessment and feedback practices: A critical review of engineering education settings. EURASIA Journal of Mathematics, Science and Technology Education, 16(3), em1829.

Wildeman, R. (2008). How budgetary frameworks support meaningful access to education. South African child gange, 2009.

Zuze, T. L. (2008). Equity and effectiveness in East African primary schools (Doctoral dissertation). University of Cape Town, South Africa.

\section{Annex 1 Pupil Questionnaire}

\section{Key: SA=Strongly Agree, A=Agree, UD=Undecided, D=Disagree, SD=Strongly Disagree \\ TICK ONLY ONE BOX PER QUESTION}

Indicate how well the school does the following:

\begin{tabular}{|c|c|c|c|c|c|c|}
\hline A & Pedagogy & SA & A & UD & D & SD \\
\hline 1 & Teachers are always on time for the lessons & & & & & \\
\hline 2 & Teachers keep us meaningfully busy during each lesson & & & & & \\
\hline 3 & $\begin{array}{l}\text { Teachers help us individually when we do not understand } \\
\text { subjects }\end{array}$ & & & & & \\
\hline 4 & We have enough teachers for each subject in my school & & & & & \\
\hline 5 & $\begin{array}{l}\text { Teachers are capable of using different teaching methods to } \\
\text { increase the quality of learning }\end{array}$ & & & & & \\
\hline B & Time-on-task & & & & & \\
\hline 1 & There is extra learning before and after flooding & & & & & \\
\hline 2 & $\begin{array}{l}\text { There is frequent pupil absenteeism during flooding due to } \\
\text { unfavourable environments. }\end{array}$ & & & & & \\
\hline 3 & $\begin{array}{l}\text { There is forced repetition due to poor performance in my } \\
\text { school. }\end{array}$ & & & & & \\
\hline 4 & $\begin{array}{l}\text { There is significant learning time lost during and after } \\
\text { flooding }\end{array}$ & & & & & \\
\hline 5 & I would achieve more if I had more learning time at school & & & & & \\
\hline C & Resources & & & & & \\
\hline 1 & There are enough toilet facilities at school & & & & & \\
\hline 2 & There are enough text books in my school & & & & & \\
\hline 3 & There are enough classrooms in my school & & & & & \\
\hline 4 & There are enough pupils' desks in the school & & & & & \\
\hline 5 & The classrooms are permanent structures to counter floods & & & & & \\
\hline
\end{tabular}




\begin{tabular}{|l|l|l|l|l|l|l|}
\hline D & Parental Involvement & & & & & \\
\hline 1 & $\begin{array}{l}\text { My parent's involvement in my school work helps me } \\
\text { succeed more }\end{array}$ & & & & \\
\hline 2 & $\begin{array}{l}\text { School and family interactions are very important towards } \\
\text { education achievement }\end{array}$ & & & & \\
\hline 3 & We have several parents meetings at school & & & & & \\
\hline 4 & My parent ensures I get to school during floods & & & & & \\
\hline 5 & My parent prepares well with me before floods & & & & \\
\hline & \multicolumn{1}{|l|}{$\begin{array}{l}\text { Please write a paragraph of your own personal } \\
\text { experience with floods and learning }\end{array}$} & & & & & \\
\hline
\end{tabular}

